\title{
EFFECT OF THE SUBSTRATE COMPOSITION ON YIELD AND QUALITY OF BASIL (OCIMUM BASILICUM L.)
}

\author{
Irina BURDINA*, Olesia PRISS \\ Tavria State Agrotechnological University \\ 18 Khmelnytsky avenue, 72310 Melitopol, Ukraine \\ Received: July 2016; Accepted: December 2016
}

\begin{abstract}
Basil (Ocimum basilicum L.) is an aromatic herb which has a high value and is of high demand in the world. Basil in Ukraine is grown mainly in small farms and country house gardens. The influence of the substrate composition (proportions of peat to perlite) on the yield of herbs and on the accumulation of biologically active substances with antioxidant properties was studied for two cultivars grown in a greenhouse. It was found that the substrate composition influenced the fresh and dry weight, as well as level of total phenolic compounds, carotenoids and essential oils of basil. The herbs yield, ascorbic acid and essential oils concentration increased at an addition of 20,40 and $60 \%$ of perlite, and decreased at $80 \%$ as compared to $100 \%$ peat. Plants of both cultivars accumulated the highest amount of phenolic substances when grown in the substrate, which contained $40 \%$ of peat and $60 \%$ of perlite. The concentration of ascorbic acid increased in plants grown in the substrates with 20,40 and $60 \%$ of perlite, mostly at $40 \%$. Significant increase in the concentration of carotenoids differed for cultivars and in 'Bad'oryi' cv. increased at 20 and $40 \%$ perlite, but in 'Filosof' at 20, 40 and $60 \%$.
\end{abstract}

Key words: basil, yield, total phenolic compounds, ascorbic acid, carotenoids, essential oil, substrate

\section{INTRODUCTION}

Aromatic herbs have high antioxidant activity, which is caused by the presence of high content of different classes of biologically active substances (Dapkevicius et al. 1998; Suhaj 2006) that play an important role in the prevention of many diseases due to the detoxification of reactive oxygen species.

Basil (Ocimum basilicum), which belongs to the Lamiaceae family, is one of the most popular herbs being grown extensively in many climatic zones, and it's consumer demand is increasing. Fresh or dried flowers and leaves of basil are used as food ingredients, in medicine and cosmetology (Nurzyńska-Wierdak 2012) and in landscape design as an ornamental scent plant (Makri \& Kintzios 2008). It was shown that basil plants accumulate quite a lot of biologically active sub- stances with antioxidant properties (Kwee \& Niemeyer 2011; Surveswaran et al. 2007), including ascorbic acid, carotenoids, polyphenolics, and essential oils (0.1-0.2\%) (Zheng \& Wang 2001; Shan et al. 2005).

Experimental studies have revealed that such factors as genotype, light intensity and quality (Shiga et al. 2009; Shoji et al. 2009), moisture content (Heidari \& Golpayegani 2012), mineral nutrition (Nguyen \& Niemeyer 2008), salinity (Tarchoune et al. 2012) have a significant effect on yield and accumulation of biologically active substances in basil. However, no data showing the effect of different substrates under greenhouse conditions on the accumulation of antioxidants is available. This fact substantiates the relevance of study on the impact of composition of substrates on the herb's yield and the content of active ingredients in basil cultivated in a greenhouse. 


\section{MATERIALS AND METHODS}

Two basil cultivars of Ukrainian selection, 'Bad'oryi' with green leaves and 'Filosof' with purple leaves, were used in the experiment.

Peat and perlite mixtures (fractions $2-5 \mathrm{~mm}$ ) in different proportions were used: 1 - peat $100 \%$ (the control); 2 - peat $80 \%$, perlite $-20 \% ; 3$ - peat $60 \%$, perlite $40 \% ; 4$ - peat $40 \%$, perlite $60 \% ; 5-$ peat $20 \%$, perlite $80 \%$.

The degree of peat decomposition was $10 \%$, ash content was $6 \%$, peat density was $0.15 \mathrm{~g} \cdot \mathrm{cm}^{-3}$, porosity was $86 \%$ and the content of particles of 6 $16 \mathrm{~mm}$ size was up to $80 \%$. Substrates humidity was at $70-75 \%$. Fertilizer contained $\mathrm{N}-110, \mathrm{P}-30$, $\mathrm{K}-170, \mathrm{Mg}-45 \mathrm{~g} \cdot \mathrm{dm}^{-3}$ was added into the prepared substrates. Additionally, the solution of fertilizers was applied with drip irrigation after each cutting of the green mass of basil: $\mathrm{N}-40, \mathrm{P}-10$, $\mathrm{K}-60, \mathrm{Mg}-15, \mathrm{Ca}-140 \mathrm{~g} \cdot \mathrm{dm}^{-3}$. The $\mathrm{pH}$ was neutral and ranged from 6.2 in the peat to 7.0 in the substrate with highest rate of perlite.

The experiment was conducted under the greenhouse conditions in years 2014-2015. Seeds were sown in the 2 nd decade of March. At the phase of 1-2 leaves, the plants were transplanted into pots of $6 \times 6 \mathrm{~cm}$. At the phase of 3-4 leaves, the seedlings were transplanted to the above substrates, to the same size of pots with the planting scheme $30 \times 20 \mathrm{~cm}\left(16\right.$ plants per $\left.\mathrm{m}^{2}\right)$. Air temperature in the greenhouse was maintained at $27^{\circ} \mathrm{C} / 22^{\circ} \mathrm{C}$ (day/night). Relative humidity in the greenhouse ranged between $92.0-96.0 \%$.

In each experimental treatment, there were 5 plants, and it was repeated 5 times. Green mass was harvested at every $14 \mathrm{~d}$ approximately, by cutting the shoot tips $15-20 \mathrm{~cm}$ in length and it was weighed immediately after harvest. The samples (500 $\mathrm{g}$ in 5 times repeated) for determining the content of total polyphenolic compounds, ascorbic acid, carotenoids and essential oils were selected from 25 test plants at the inflorescence growth phase.

All data were analyzed statistically using Agrostat New software (developed by the local Agricultural University) and Microsoft Excel. We used the three-factorial analysis of variance for the calculations. Significant differences between individual means were determined using Fisher's protected least significant difference (LSD) test, with the level of significance set at $5 \%$.

\section{Determination of total phenolic content}

The content of polyphenolic compounds was determined by Folin-Denis reagent (DSTU 4373:2005 2006). The method comprised complexation reaction of polyphenols with Folin-Denis reagent and the formation of colored substances, followed by determination of the optical density of solution.

The samples $(4.0 \mathrm{~g})$ were quantitatively transferred to a conical flask of $50 \mathrm{~cm}^{3}$, pre-warmed to $60{ }^{\circ} \mathrm{C} 75 \%$ ethanol was added. For inactivation of enzymes, the flask was kept for 15 minutes in a water bath at $80^{\circ} \mathrm{C}$. After cooling, the extract was quantitatively transferred to a volumetric flask and adjusted to $50 \mathrm{~cm}^{3}$ by $75 \%$ ethanol. The obtained extract was thoroughly stirred and filtered.

Preparation of the eluate $\left(D_{1}\right): 1 \mathrm{~cm}^{3}$ of the extract was transferred to a test tube containing $7.5 \mathrm{~cm}^{3}$ of distilled water to which $0.5 \mathrm{~cm}^{3}$ of the Folin-Denis reagent was added. After 3 minutes, $1 \mathrm{~cm}^{3}$ of saturated sodium carbonate solution was added.

Preparation of the control of eluate $\left(D_{k}\right)$ : for monitoring of the colored substances in the second tube, $1 \mathrm{~cm}^{3}$ of the extract, $8.0 \mathrm{~cm}^{3}$ of the distilled water and $1 \mathrm{~cm}^{3}$ of saturated sodium carbonate solution were transferred without adding Folin-Dennis reagent. Preparation of control solution (K): $8.5 \mathrm{~cm}^{3}$ of distilled water was poured into the test tube. Then $0.5 \mathrm{~cm}^{3}$ of Folin-Denis reagent and $1 \mathrm{~cm}^{3}$ of sodium carbonate solution were added into the tube. After 60 minutes, the eluate $\left(D_{1}\right)$ was measured spectrophotometrically in the presence of the control solution $(K)$; control of eluate $\left(D_{k}\right)$ was measured in the presence of distilled water. The measurements were carried out at a wavelength of $670 \mathrm{~nm}$. The optical density of the sample was determined according to the formula: $\mathrm{D}=\mathrm{D}_{1}-\mathrm{D}_{\mathrm{k}}$. The amount of phenols was determined by the calibration curve constructed with quercetin.

\section{Determination of vitamin C}

In order to determine the vitamin $\mathrm{C}$ content, the iodometric method was used (Naichenko 2001). The essence of the method is in the measurement of reducing power of ascorbic acid. In this method, ascorbic acid is oxidized and restores the potassium 
iodide to free iodine. The amount of free iodine is defined by the color reaction with a starch.

The samples $(2.0-10.0 \mathrm{~g})$ were weighed and triturated with a small amount of water in a porcelain mortar. Then the substance was quantitatively transferred to a volumetric flask of $100 \mathrm{~cm}^{3}$, adjusted to the mark and filtered. For titration, $10 \mathrm{~cm}^{3}$ of extract was taken and $1 \mathrm{~cm}^{3}$ of $2 \% \mathrm{HCl}, 0.5 \mathrm{~cm}^{3}$ of $1 \%$ potassium iodine solution, $2 \mathrm{~cm}^{3}$ of $0.5 \%$ starch solution and $6-7 \mathrm{~cm}^{3}$ of distilled water were added. Titration with $0.01 \mathrm{~N}$ solution of potassium iodide was conducted until a persistent blue color appeared. At the same time, the control titration using $10 \mathrm{~cm}^{3}$ of water instead of an extract was also conducted. Quantification of vitamin C content was done according to the relation: $1 \mathrm{~cm}^{3} 0.01 \mathrm{~N}$ potassium iodide is equivalent to $0.8806 \mathrm{mg}$ of vitamin C. All determinations were performed in triplicate, with calculating their mean arithmetic value.

\section{Determination of carotenoids}

The content of carotenoids was determined spectrophotometrically by extracting the pigments with $100 \%$ acetone with subsequent determination of optical density of pigments at the wavelength of $440.5 \mathrm{~nm}$ (Musiyenko et al. 2001).

For the experiment, samples of $150-200 \mathrm{mg}$ were taken and carefully rubbed with $\mathrm{MgCO}_{3}$ and $5 \mathrm{~cm}^{3}$ of acetone. The extract was poured through a glass filter in a volumetric flask of $25 \mathrm{~cm}^{3}$. A Bunsen flask was rinsed several times with small portions of acetone and adjusted to the mark with pure acetone. The obtained acetone extract contains the sum of green and yellow pigments. Then the measurements of optical density (D) at wavelengths of 662,644 , and $440.5 \mathrm{~nm}$ were carried out.

The concentration of pigment was calculated by the equations:

$\mathrm{X}_{(\mathrm{Chl} \mathrm{a})}=9.784 \mathrm{D}_{662}-0.990 \mathrm{D}_{644} ;$

$\mathrm{X}_{(\mathrm{Chl} \mathrm{b})}=21.426 \mathrm{D}_{644}-4.650 \mathrm{D}_{662}$;

$\mathrm{X}_{(\mathrm{Chl} \mathrm{a}+\mathrm{Chl} \mathrm{b})}=5.134 \mathrm{D}_{662}+20.436 \mathrm{D}_{644}$;

$\mathrm{X}_{\text {(Carotenoids) }}=4.695 \mathrm{D}_{440.5}-0.268 \mathrm{X}_{(\mathrm{Chl} \mathrm{a}+\mathrm{Chl} \mathrm{b})}$

The content of pigments (A) in the plant material was calculated by the formula:

$\mathrm{A}=\mathrm{X} \cdot \mathrm{v} / \mathrm{H} \cdot 100$

$\mathrm{X}-$ the pigments concentration, $\mathrm{mg} \cdot \mathrm{dm}^{-3}$;

$\mathrm{v}$ - the volume of extract, $\mathrm{ml}\left(25 \mathrm{~cm}^{3}\right)$;

$\mathrm{H}$ - the sample of plant material, $\mathrm{g}(0.1-0.2 \mathrm{~g})$.

\section{Determination of essential oils}

The amount of essential oils in basil leaves was determined by hydro distillation from the raw material of plants with steam, and a subsequent measurement of their volume expressed as a percentage relative to the dry raw material. Ginsberg installation was used for this study.

\section{RESULTS AND DISCUSSION}

Basil plants grown in the greenhouse in peatmineral substrates produced up to 5 cuttings per plant. An exception was 'Bad'oryi' when grown in substrates with the 60 and $80 \%$ of perlite, where only 3 cuttings were produced.

On an average for 2 years, the yield of fresh mass was 7.14 and $7.86 \mathrm{~kg}$ per $\mathrm{m}^{2}$, for 'Filosof' and 'Bad'oryi', respectively (Table 1). An addition of 20,40 or $60 \%$ perlite to peat caused increase of fresh and dry mass (the highest at $40 \%$ ).

The addition of $40 \%$ perlite increased the fresh mass by 34 and $33 \%$, and dry mass by 58 and $34 \%$, for 'Filosof' and 'Bad'oryi', respectively. Further saturation of substrate with perlite to $80 \%$ lowered green mass of both cultivars of basil by $59 \%$ in 'Bad'oryi' and by $40 \%$ in 'Filosof' and dry mass by 66 and $60 \%$, respectively, as compared to pure peat.

The analysis of three-factorial experiment showed that the decisive factors in shaping the yield of both cultivars of basil were the substrate factor (share of factor influence - 91.1\%), year of cultivation (share of factor influence $-3.1 \%$ ) and cultivar (share of factor influence $-2.8 \%$ ).

The above results showed the dependence of fresh and dry mass from the proportion of perlite that can be explained by their impact on physical and water properties of a growth substrate. It is well known that the growth and development of plants largely depend on specific and volumetric weight, total porosity and moisture capacity of the substrate. Peat is characterized by high porosity and low specific and volumetric weight. However, due to high water capacity, it is virtually impossible to adjust the irrigation regime. Peat becomes compacted with time, decreasing its porosity, and demonstrating the over accumulation of moisture. This leads to deterioration of the root environment. 
In turn, the supplementation with perlite contributes to the maintenance of water and air/oxygen balance of the root environment.

A necessary component of the yield of herbs is the concentration of biologically active compounds, especially those of antioxidant activity. Studies have shown that the accumulation of the biologically active substances differed with cultivar, year of cultivation and substrate.

The content of polyphenolic compounds was significantly higher in 'Filosof'. On average from two years of study, 'Filosof' with purple leaves accumulated $17.2 \%$ polyphenolic substances more than 'Bad'oryi' with green leaves (Table 2).

In 2014, the concentration of total phenolic compounds was more than two times lower than that in 2015. Similarly, as with fresh and dry mass, the concentration of total phenolic grew with an increased rate of perlite up to $60 \%$ when it was by 32 $36 \%$ higher ('Bad'oryi') and 23-24\% higher in 'Filosof' in comparison to the control (100\% peat). The lowest concentration of phenolics was found in plants grown in the substrate supplemented with $80 \%$ of perlite.

Table 1. Fresh (FW) and dry weight (DW) of basil, mean \pm SD $k g$ per $\mathrm{m}^{2}, \mathrm{n}=5$ )

\begin{tabular}{|c|c|c|c|c|c|c|c|c|c|}
\hline \multirow{3}{*}{ Cultivar } & \multirow{3}{*}{$\begin{array}{c}\text { Substrate } \\
\text { composition }\end{array}$} & \multicolumn{4}{|c|}{ Year } & \multirow{2}{*}{\multicolumn{4}{|c|}{ Mean for year }} \\
\hline & & \multicolumn{2}{|c|}{2014} & \multicolumn{2}{|c|}{2015} & & & & \\
\hline & & fresh weight & dry weight & fresh weight & $\begin{array}{c}\text { dry } \\
\text { weight }\end{array}$ & $\begin{array}{c}\text { fresh } \\
\text { weight }\end{array}$ & $\begin{array}{l}\% \text { to } \\
\text { peat }\end{array}$ & dry weight & $\begin{array}{l}\% \text { to } \\
\text { peat }\end{array}$ \\
\hline \multirow{5}{*}{ 'Bad'oryi' } & $100 \%$ peat & $7.44 \pm 0.09$ & $0.84 \pm 0.010$ & $6.78 \pm 0.04$ & $0.74 \pm 0.005$ & $7.11 \pm 0.06$ & & $0.79 \pm 0.007$ & \\
\hline & $\begin{array}{l}80 \% \text { peat }+ \\
20 \% \text { perlite }\end{array}$ & $9.19 \pm 0.10$ & $1.13 \pm 0.012$ & $8.19 \pm 0.07$ & $0.99 \pm 0.008$ & $8.69 \pm 0.07$ & $+22 \%$ & $1.06 \pm 0.009$ & $+34 \%$ \\
\hline & $\begin{array}{l}60 \% \text { peat }+ \\
40 \% \text { perlite }\end{array}$ & $9.95 \pm 0.07$ & $1.31 \pm 0.008$ & $9.14 \pm 0.03$ & $1.18 \pm 0.004$ & $9.55 \pm 0.03$ & $+34 \%$ & $1.25 \pm 0.00$ & $+58 \%$ \\
\hline & $\begin{array}{l}40 \% \text { peat }+ \\
60 \% \text { perlite } \\
\end{array}$ & $7.68 \pm 0.07$ & $0.93 \pm 0.010$ & $7.08 \pm 0.04$ & $0.88 \pm 0.004$ & $7.38 \pm 0.04$ & $+4 \%$ & $0.91 \pm 0.005$ & $+15 \%$ \\
\hline & $\begin{array}{l}20 \% \text { peat }+ \\
80 \% \text { perlite }\end{array}$ & $3.17 \pm 0.12$ & $0.29 \pm 0.010$ & $2.74 \pm 0.04$ & $0.25 \pm 0.004$ & $2.95 \pm 0.07$ & $-59 \%$ & $0.27 \pm 0.006$ & $-66 \%$ \\
\hline \multicolumn{2}{|c|}{ Mean for cultivar } & 7.49 & 0.90 & 6.79 & 0.81 & 7.14 & & 0.86 & \\
\hline \multirow{5}{*}{ 'Filosof' } & $100 \%$ peat & $7.92 \pm 0.04$ & $0.89 \pm 0.004$ & $6.83 \pm 0.10$ & $0.75 \pm 0.011$ & $7.38 \pm 0.06$ & & $0.82 \pm 0.006$ & \\
\hline & $\begin{array}{l}80 \% \text { peat }+ \\
20 \% \text { perlite }\end{array}$ & $9.37 \pm 0.07$ & $1.06 \pm 0.008$ & $8.25 \pm 0.05$ & $0.92 \pm 0.006$ & $8.81 \pm 0.04$ & $+19 \%$ & $0.99 \pm 0.004$ & $+21 \%$ \\
\hline & $\begin{array}{l}60 \% \text { peat }+ \\
40 \% \text { perlite }\end{array}$ & $10.32 \pm 0.07$ & $1.18 \pm 0.007$ & $9.24 \pm 0.05$ & $1.02 \pm 0.005$ & $9.78 \pm .04$ & $+33 \%$ & $1.10 \pm 0.004$ & $+34 \%$ \\
\hline & $\begin{array}{l}40 \% \text { peat }+ \\
60 \% \text { perlite } \\
\end{array}$ & $9.26 \pm 0.06$ & $1.04 \pm 0.007$ & $8.55 \pm 0.02$ & $0.95 \pm 0.002$ & $8.91 \pm 0.03$ & $+21 \%$ & $1.00 \pm 0.004$ & $+22 \%$ \\
\hline & $\begin{array}{l}20 \% \text { peat }+ \\
80 \% \text { perlite }\end{array}$ & $4.44 \pm 0.04$ & $0.40 \pm 0.003$ & $4.38 \pm 0.11$ & $0.27 \pm 0.007$ & $4.41 \pm 0.06$ & $-40 \%$ & $0.33 \pm 0.004$ & $-60 \%$ \\
\hline \multicolumn{2}{|c|}{ Mean for cultivar } & 8.26 & 0.92 & 7.45 & 0.78 & 7.86 & & 0.85 & \\
\hline \multirow{5}{*}{$\begin{array}{l}\text { Mean for } \\
\text { substrate }\end{array}$} & $100 \%$ peat & 7.68 & 0.87 & 6.81 & 0.75 & 7.25 & & 0.81 & \\
\hline & $\begin{array}{l}80 \% \text { peat }+ \\
20 \% \text { perlite }\end{array}$ & 9.28 & 1.1 & 8.22 & 0.96 & 8.75 & & 1.03 & \\
\hline & $\begin{array}{l}60 \% \text { peat }+ \\
40 \% \text { perlite }\end{array}$ & 10.14 & 1.25 & 9.19 & 1.10 & 9.67 & & 1.18 & \\
\hline & $\begin{array}{l}40 \% \text { peat }+ \\
60 \% \text { perlite } \\
\end{array}$ & 8.47 & 1.00 & 7.57 & 0.92 & 8.15 & & 0.96 & \\
\hline & $\begin{array}{l}20 \% \text { peat }+ \\
80 \% \text { perlite }\end{array}$ & 3.81 & 0.35 & 3.56 & 0.26 & 3.68 & & 0.30 & \\
\hline \multicolumn{2}{|l|}{ Mean } & 7.88 & 0.91 & 7.12 & 0.80 & 7.20 & & 0.86 & \\
\hline
\end{tabular}

$\mathrm{LSD}_{0.05} \mathrm{FW} / \mathrm{DW}$ : year - 0.1/0.001; cultivar - 0.2/0.002; substrate $-0.2 / 0.002$ 
Table 2. Total phenolic compounds (TPC) of basil, $\mathrm{mg} \times 100 \cdot \mathrm{g}^{-1}$ of fresh mass were added into the prepared substrates:, mean $\pm \mathrm{SD},(\mathrm{n}=5)$

\begin{tabular}{|c|c|c|c|c|c|c|c|}
\hline \multirow{3}{*}{ Cultivar } & \multirow{3}{*}{$\begin{array}{l}\text { Substrate } \\
\text { composition }\end{array}$} & \multicolumn{4}{|c|}{ Year } & \multirow{2}{*}{\multicolumn{2}{|c|}{ Mean for year }} \\
\hline & & \multicolumn{2}{|c|}{2014} & \multicolumn{2}{|c|}{2015} & & \\
\hline & & $\mathrm{TPC} \pm \mathrm{SD}$ & $\%$ to peat & $\mathrm{TPC} \pm \mathrm{SD}$ & $\%$ to peat & $\mathrm{TPC} \pm \mathrm{SD}$ & $\%$ to peat \\
\hline \multirow{5}{*}{ 'Bad'oryi' } & $100 \%$ peat & $166.7 \pm 0.66$ & & $434.3 \pm 1.69$ & & $300.5 \pm 0.97$ & \\
\hline & $\begin{array}{l}80 \% \text { peat }+ \\
20 \% \text { perlite }\end{array}$ & $178.0 \pm 1.26$ & $+7 \%$ & $520.6 \pm 2.71$ & $+20 \%$ & $349.3 \pm 1.83$ & $+16 \%$ \\
\hline & $\begin{array}{l}60 \% \text { peat }+ \\
40 \% \text { perlite }\end{array}$ & $200.2 \pm 1.14$ & $+20 \%$ & $571.0 \pm 3.13$ & $+31 \%$ & $385.6 \pm 1.44$ & $+28 \%$ \\
\hline & $\begin{array}{l}40 \% \text { peat }+ \\
60 \% \text { perlite }\end{array}$ & $219.5 \pm 1.26$ & $+32 \%$ & $591.8 \pm 11.55$ & $+36 \%$ & $405.6 \pm 6.21$ & $+35 \%$ \\
\hline & $\begin{array}{l}20 \% \text { peat }+ \\
80 \% \text { perlite }\end{array}$ & $143.9 \pm 2.27$ & $-14 \%$ & $409.5 \pm 3.66$ & $-6 \%$ & $276.7 \pm 2.02$ & $-8 \%$ \\
\hline \multicolumn{2}{|c|}{ Mean for cultivar } & 181.8 & $+9 \%$ & 505.6 & $+16 \%$ & 343.8 & $+14 \%$ \\
\hline \multirow{5}{*}{ 'Filosof' } & $100 \%$ peat & $216.6 \pm 1.12$ & & $509.8 \pm 7.98$ & & $363.2 \pm 4.07$ & \\
\hline & $\begin{array}{l}80 \% \text { peat }+ \\
20 \% \text { perlite } \\
\end{array}$ & $233.1 \pm 1.52$ & $+8 \%$ & $570.6 \pm 1.57$ & $+12 \%$ & $401.9 \pm 0.49$ & $+11 \%$ \\
\hline & $\begin{array}{l}60 \% \text { peat }+ \\
40 \% \text { perlite } \\
\end{array}$ & $256.5 \pm 0.85$ & $+18 \%$ & $604.0 \pm 2.55$ & $+19 \%$ & $430.3 \pm 1.61$ & $+18 \%$ \\
\hline & $\begin{array}{l}40 \% \text { peat }+ \\
60 \% \text { perlite } \\
\end{array}$ & $266.0 \pm 1.07$ & $+23 \%$ & $633.5 \pm 2.42$ & $+24 \%$ & $449.8 \pm 1.02$ & $+24 \%$ \\
\hline & $\begin{array}{l}20 \% \text { peat }+ \\
80 \% \text { perlite }\end{array}$ & $204.8 \pm 3.79$ & $-9 \%$ & $530.0 \pm 9.81$ & $+4 \%$ & $367.4 \pm 3.13$ & $+1 \%$ \\
\hline \multicolumn{2}{|c|}{ Mean for cultivar } & 235.6 & & 569.8 & & 402.4 & \\
\hline \multirow{5}{*}{$\begin{array}{l}\text { Mean for } \\
\text { substrate }\end{array}$} & $100 \%$ peat & 191.7 & & 472.1 & & 324.7 & \\
\hline & $\begin{array}{l}80 \% \text { peat }+ \\
20 \% \text { perlite }\end{array}$ & 205.6 & & 545.6 & & 375.6 & \\
\hline & $\begin{array}{l}60 \% \text { peat }+ \\
40 \% \text { perlite } \\
\end{array}$ & 228.4 & & 587.5 & & 408.0 & \\
\hline & $\begin{array}{l}40 \% \text { peat }+ \\
60 \% \text { perlite } \\
\end{array}$ & 242.8 & & 612.7 & & 427.7 & \\
\hline & $\begin{array}{l}20 \% \text { peat }+ \\
80 \% \text { perlite }\end{array}$ & 174.4 & & 469.8 & & 322.1 & \\
\hline \multicolumn{2}{|c|}{ Mean for year } & 208.7 & & 537.7 & & 373.1 & \\
\hline
\end{tabular}

Studies of other authors show that basil with purple leaves accumulate more phenols in comparison with green-leaf cultivars. For example, Juliani and Simon (2002) reported that purple leaves basil cultivars contained from 126.2 to $81.7 \mathrm{mg}$ phenolic per $1 \mathrm{~g}$ dry weight while the green leaves cultivars from 35.6 to $62.9 \mathrm{mg}$ per $\mathrm{g}$ of dry weight. This fact can be explained by the presence of anthocyanins in pigment complex of purple basil.

The accumulation of phenolic substances was dependent on the year of study (the share of factor influence $-89.8 \%$ ), cultivars (the share of factor influence $-2.9 \%$ ) and substrates (the share of factor influence $-5.6 \%$ ).

The production and accumulation of phenolic compounds is a process largely dependent on many environmental factors. Given the fact that the temperature in the greenhouse was maintained at the same level $\left(25-27^{\circ} \mathrm{C}\right)$, the main uncontrolled factor, which could greatly affect the yield and accumulation of biologically active substances was the intensity of sunlight. The flow of basic metabolic 
processes such as photosynthesis, respiration, transpiration, root and foliar nutrition of plants depends on the sunlight (Chang et al. 2008).

Light level at the stage of formation of 1 pair of leaves - budding period was diverse through years. Thus, the total cloudiness of the third 10 days of March - first 10 days of April 2015 was 67 points, and the lowest level of the cloudiness was 5 points; while in 2014 these rates were at 3 and 1, respectively. The second and third 10 days of April almost did not differ for years; total cloudiness was 4-5 points, and the lowest level of the cloudiness was 2 points. The first 10 days of May 2015 was characterized by higher cloudiness. During this period, the total cloudiness was 7 points, and the lowest level was 5 points, while in 2014, these indices were at 4 and 1 points respectively. There are many publications that show differences in polyphenols content depending on the harvest season, year, light levels, etc. (Proestos et al. 2005; Atoui et al. 2005; Škerget et al. 2005; Katalinic et al. 2006).

The content of ascorbic acid in both cultivars ranged from 14.0 to $26.9 \mathrm{mg}$ per $100 \mathrm{~g}$ of fresh weight. Similar results were obtained in studies by other authors (Holland et al. 1991; Dumbravă et al. 2012). In our study, on an average, the cultivar with purple leaves accumulates $18.4 \%$ more ascorbic acid than green-leaves cultivar. The tendency in vitamin $\mathrm{C}$ accumulation was also dependent on the substrate composition but the highest was at $40 \%$ of perlite (Table 3 ).

Table 3. Ascorbic acid (AA) in basil, $\mathrm{mg} \times 100 \mathrm{~g}^{-1}$ of fresh mass, mean $\pm \mathrm{SD},(\mathrm{n}=5)$

\begin{tabular}{|c|c|c|c|c|c|c|c|}
\hline \multirow{3}{*}{ Cultivar } & \multirow{3}{*}{$\begin{array}{l}\text { Substrate com- } \\
\text { position }\end{array}$} & \multicolumn{4}{|c|}{ Year } & \multirow{2}{*}{\multicolumn{2}{|c|}{ Average for year }} \\
\hline & & \multicolumn{2}{|c|}{2014} & \multicolumn{2}{|c|}{2015} & & \\
\hline & & $\mathrm{AA} \pm \mathrm{SD}$ & $\%$ to peat & $\mathrm{AA} \pm \mathrm{SD}$ & $\%$ to peat & $\mathrm{AA} \pm \mathrm{SD}$ & $\%$ to peat \\
\hline \multirow{5}{*}{ 'Bad'oryi' } & $100 \%$ peat & $14.00 \pm 0.45$ & & $16.84 \pm 0.35$ & & $15.41 \pm 0.29$ & \\
\hline & $\begin{array}{l}80 \% \text { peat }+ \\
20 \% \text { perlite }\end{array}$ & $16.60 \pm 0.63$ & $+19 \%$ & $18.60 \pm 0.55$ & $+10 \%$ & $17.61 \pm 0.56$ & $+14 \%$ \\
\hline & $\begin{array}{l}60 \% \text { peat }+ \\
40 \% \text { perlite } \\
\end{array}$ & $20.50 \pm 1.48$ & $+46 \%$ & $23.56 \pm 0.45$ & $+40 \%$ & $22.02 \pm 0.52$ & $+43 \%$ \\
\hline & $\begin{array}{l}40 \% \text { peat }+ \\
60 \% \text { perlite } \\
\end{array}$ & $17.10 \pm 0.79$ & $+22 \%$ & $21.02 \pm 1.21$ & $+25 \%$ & $19.10 \pm 0.75$ & $+24 \%$ \\
\hline & $\begin{array}{l}20 \% \text { peat }+ \\
80 \% \text { perlite } \\
\end{array}$ & $14.44 \pm 1.28$ & $+3 \%$ & $18.60 \pm 0.79$ & $+10 \%$ & $15.03 \pm 0.45$ & $-2 \%$ \\
\hline \multicolumn{2}{|c|}{ Mean for cultivar } & 16.5 & $+18 \%$ & 19.72 & $+17 \%$ & 17.83 & $+16 \%$ \\
\hline \multirow{5}{*}{ 'Filosof' } & $100 \%$ peat & $18.16 \pm 1.07$ & & $19.50 \pm 0.30$ & & $18.82 \pm 0.39$ & \\
\hline & $\begin{array}{l}80 \% \text { peat }+ \\
20 \% \text { perlite } \\
\end{array}$ & $21.57 \pm 0.20$ & $+19 \%$ & $22.57 \pm 0.66$ & $+15.7 \%$ & $22.07 \pm 0.31$ & $+17 \%$ \\
\hline & $\begin{array}{l}60 \% \text { peat }+ \\
40 \% \text { perlite } \\
\end{array}$ & $25.76 \pm 0.82$ & $+42 \%$ & $26.86 \pm 0.28$ & $+38 \%$ & $26.31 \pm 0.36$ & $+40 \%$ \\
\hline & $\begin{array}{l}40 \% \text { peat }+ \\
60 \% \text { perlite } \\
\end{array}$ & $22.20 \pm 0.41$ & $+22 \%$ & $19.70 \pm 0.58$ & $+1 \%$ & $21.00 \pm 0.33$ & $+12 \%$ \\
\hline & $\begin{array}{l}20 \% \text { peat }+ \\
80 \% \text { perlite }\end{array}$ & $15.74 \pm 0.36$ & $-13 \%$ & $18.8 \pm 0.38$ & $-4 \%$ & $17.28 \pm 0.20$ & $-8 \%$ \\
\hline \multicolumn{2}{|c|}{ Mean for cultivar } & 20.69 & & 21.49 & & 21.10 & \\
\hline \multirow{5}{*}{$\begin{array}{l}\text { Mean for } \\
\text { substrate }\end{array}$} & $100 \%$ peat & 16.08 & & 18.17 & & 17.12 & \\
\hline & $\begin{array}{l}80 \% \text { peat }+ \\
20 \% \text { perlite } \\
\end{array}$ & 19.01 & & 20.59 & & 21.96 & \\
\hline & $\begin{array}{l}60 \% \text { peat }+ \\
40 \% \text { perlite }\end{array}$ & 23.13 & & 25.21 & & 24.17 & \\
\hline & $\begin{array}{l}40 \% \text { peat }+ \\
60 \% \text { perlite } \\
\end{array}$ & 19.65 & & 20.36 & & 20.10 & \\
\hline & $\begin{array}{l}20 \% \text { peat }+ \\
80 \% \text { perlite }\end{array}$ & 15.05 & & 18.7 & & 16.16 & \\
\hline \multicolumn{2}{|c|}{ Mean for year } & 18.6 & & 20.61 & & 19.47 & \\
\hline
\end{tabular}


In this experimental variant, the vitamin $\mathrm{C}$ content increased by $43.4 \%$ in 'Bad'oryi' and by $39.1 \%$ in 'Filosof' in comparison with the control variant. The further saturation of the substrate with perlite was ineffective. It was established that the substrates have a determining influence on the accumulation of vitamin $\mathrm{C}$ in basil. Also, more ascorbic acid was noted in 2015; it concerned mostly greenleaf cultivar. The share of substrate factor influence was $55.7 \%$, the share of cultivar factor was $18.9 \%$ and the share of year factor was $9.3 \%$.
Supplementation of the substrates with perlite had much weaker influence on the accumulation of carotenoids in basil plants (Table 4). Carotenoids are a class of secondary plant compounds with multiple functions such as: structure stabilization, light harvesting and energy dissipation (Kopsell et al. 2005). Also, they have an important role in the protection of plants from photooxidative (Mortensen et al. 2001). The studies of other authors showed that the level of carotenoids of basil can vary between $0.38 \mathrm{mg} \cdot \mathrm{g}^{-1}$ (Hawrylak-Nowak 2008) to $59 \mathrm{mg} \cdot \mathrm{g}^{-1}$ (Matea et al. 2010).

Table 4. Carotenoids (C) in basil, $\mathrm{mg} \times 100 \mathrm{~g}^{-1}$ of fresh mass, mean $\pm \mathrm{SD},(\mathrm{n}=5)$

\begin{tabular}{|c|c|c|c|c|c|c|c|}
\hline \multirow{3}{*}{ Cultivar } & \multirow{3}{*}{$\begin{array}{l}\text { Substrate com- } \\
\text { position }\end{array}$} & \multicolumn{4}{|c|}{ Year } & \multirow{2}{*}{\multicolumn{2}{|c|}{ Mean for year }} \\
\hline & & \multicolumn{2}{|c|}{2014} & \multicolumn{2}{|c|}{2015} & & \\
\hline & & $\mathrm{C} \pm \mathrm{SD}$ & $\%$ to peat & $\mathrm{C} \pm \mathrm{SD}$ & $\%$ to peat & $\mathrm{C} \pm \mathrm{SD}$ & $\%$ to peat \\
\hline \multirow{5}{*}{ ‘Bad'oryi' } & $100 \%$ peat & $37.0 \pm 0.45$ & & $39.0 \pm 1.14$ & & $38.0 \pm 0.58$ & \\
\hline & $\begin{array}{l}80 \% \text { peat }+ \\
20 \% \text { perlite } \\
\end{array}$ & $42.4 \pm 0.81$ & $+15 \%$ & $39.8 \pm 1.24$ & $+2 \%$ & $41.1 \pm 0.51$ & $+8 \%$ \\
\hline & $\begin{array}{l}60 \% \text { peat }+ \\
40 \% \text { perlite } \\
\end{array}$ & $46.2 \pm 1.02$ & $+25 \%$ & $41.0 \pm 0.71$ & $+5 \%$ & $43.6 \pm 0.37$ & $+15 \%$ \\
\hline & $\begin{array}{l}40 \% \text { peat }+ \\
60 \% \text { perlite } \\
\end{array}$ & $32.6 \pm 1.29$ & $-12 \%$ & $35.0 \pm 0.32$ & $-10 \%$ & $34.0 \pm 0.58$ & $-11 \%$ \\
\hline & $\begin{array}{l}20 \% \text { peat }+ \\
80 \% \text { perlite } \\
\end{array}$ & $25.4 \pm 1.08$ & $-31 \%$ & $26.0 \pm 0.71$ & $-33 \%$ & $25.7 \pm 0.74$ & $-32 \%$ \\
\hline \multicolumn{2}{|c|}{ Mean for cultivar } & 36.7 & $-1 \%$ & 36.2 & $-7 \%$ & 36.5 & $-4 \%$ \\
\hline \multirow{5}{*}{ 'Filosof' } & $100 \%$ peat & $42.2 \pm 1.28$ & & $40.4 \pm 1.78$ & & $41.3 \pm 0.97$ & \\
\hline & $\begin{array}{l}80 \% \text { peat }+ \\
20 \% \text { perlite } \\
\end{array}$ & $45.4 \pm 0.40$ & $+8 \%$ & $45.0 \pm 0.32$ & $+11 \%$ & $45.2 \pm 0.25$ & $+9 \%$ \\
\hline & $\begin{array}{l}60 \% \text { peat }+ \\
40 \% \text { perlite } \\
\end{array}$ & $49.6 \pm 0.25$ & $+18 \%$ & $46.6 \pm 0.75$ & $+15 \%$ & $48.1 \pm 0.40$ & $+16 \%$ \\
\hline & $\begin{array}{l}40 \% \text { peat }+ \\
60 \% \text { perlite } \\
\end{array}$ & $50.0 \pm 0.89$ & $+18 \%$ & $47.2 \pm 0.37$ & $+17 \%$ & $48.6 \pm 0.58$ & $+18 \%$ \\
\hline & $\begin{array}{l}20 \% \text { peat }+ \\
80 \% \text { perlite } \\
\end{array}$ & $32.8 \pm 1.36$ & -22.2 & $34.8 \pm 1.24$ & $-14 \%$ & $33.8 \pm 0.89$ & $-18 \%$ \\
\hline \multicolumn{2}{|c|}{ Mean for cultivar } & 44.0 & & 42.8 & & 43.4 & \\
\hline \multirow{5}{*}{$\begin{array}{l}\text { Mean for } \\
\text { substrate }\end{array}$} & $100 \%$ peat & 39.6 & & 39.7 & & 39.7 & \\
\hline & $\begin{array}{l}80 \% \text { peat }+ \\
20 \% \text { perlite } \\
\end{array}$ & 43.5 & & 42.4 & & 43.2 & \\
\hline & $\begin{array}{l}60 \% \text { peat }+ \\
40 \% \text { perlite } \\
\end{array}$ & 47.5 & & 43.8 & & 45.9 & \\
\hline & $\begin{array}{l}40 \% \text { peat }+ \\
60 \% \text { perlite } \\
\end{array}$ & 41.3 & & 41.1 & & 41.3 & \\
\hline & $\begin{array}{l}20 \% \text { peat }+ \\
80 \% \text { perlite }\end{array}$ & 29.1 & & 30.4 & & 29.8 & \\
\hline \multicolumn{2}{|c|}{ Mean for year } & 40.4 & & 39.5 & & 40.0 & \\
\hline
\end{tabular}

LSD 0.05 carotenoids: year -4.4 ; cultivar -4.9 ; substrate -2.4 . 
Table 4 shows that the highest increase in carotenoid level of both cultivars occurred at $40 \%$ of perlite and was higher by $15 \%$ for 'Bad'oryi' and by $17 \%$ in 'Filosof' in comparison with the control. On the substrate which contained only $20 \%$ of peat and $80 \%$ of perlite carotenoid levels decreased by 1.5 times in 'Bad'oryi' and by 1.2 times in 'Filosof' Significant impact on the accumulation of carotenoids in the pigment complex of basil was provided both by substrate (substrate factor share $57.7 \%$ ) and cultivar (cultivar factor share $-23.2 \%$ ). The action of year of culture was insignificant (the share of factor $-0.4 \%$ ).
The concentration of essential oils in the leaves of both cultivars ranged between $0.09 \%-0.19 \%$ and on average was $21 \%$ more in basil with green leaves (Table 5).

In 'Bad'oryi', the same concentration of essential oils was at 20,40 and $60 \%$ of perlite in both years of culture and in 'Filosof' at 40 and 60\% of perlite in 2014 and 2015; but in the second year, the increment was higher and reached $86 \%$ in comparison with control (100\% peat). When $80 \%$ of perlite was added to the substrate, the content of essential oils had reduced by 24 and $46 \%$ compared to the control.

Table 5. Essential oils (EO) in basil, \% of fresh mass, mean $\pm \operatorname{SD},(n=5)$

\begin{tabular}{|c|c|c|c|c|c|c|c|}
\hline \multirow{3}{*}{ Cultivar } & \multirow{3}{*}{$\begin{array}{c}\text { Substrate } \\
\text { composition }\end{array}$} & \multicolumn{4}{|c|}{ Year } & \multirow{2}{*}{\multicolumn{2}{|c|}{ average for year }} \\
\hline & & \multicolumn{2}{|c|}{2014} & \multicolumn{2}{|c|}{2015} & & \\
\hline & & $\mathrm{M} \pm \mathrm{SD}$ & $\%$ to peat & $\mathrm{M} \pm \mathrm{SD}$ & $\%$ to peat & $\mathrm{M} \pm \mathrm{SD}$ & $\%$ to peat \\
\hline \multirow{5}{*}{ ‘Bad'oryi' } & $100 \%$ peat & $0.20 \pm 0.009$ & & $0.12 \pm 0.002$ & & $0.16 \pm 0.005$ & \\
\hline & $\begin{array}{l}80 \% \text { peat }+ \\
20 \% \text { perlite } \\
\end{array}$ & $0.23 \pm 0.007$ & $+15 \%$ & $0.15 \pm 0.004$ & $+25 \%$ & $0.19 \pm 0.003$ & $+19 \%$ \\
\hline & $\begin{array}{l}60 \% \text { peat }+ \\
40 \% \text { perlite } \\
\end{array}$ & $0.23 \pm 0.006$ & $+15 \%$ & $0.16 \pm 0.005$ & $+33 \%$ & $0.19 \pm 0.005$ & $+19 \%$ \\
\hline & $\begin{array}{l}40 \% \text { peat }+ \\
60 \% \text { perlite } \\
\end{array}$ & $0.23 \pm 0.005$ & $+15 \%$ & $0.15 \pm 0.007$ & $+25 \%$ & $0.19 \pm 0.006$ & $+19 \%$ \\
\hline & $\begin{array}{l}20 \% \text { peat }+ \\
80 \% \text { perlite } \\
\end{array}$ & $0.17 \pm 0.010$ & $-15 \%$ & $0.10 \pm 0.013$ & $-17 \%$ & $0.13 \pm 0.011$ & $-19 \%$ \\
\hline \multicolumn{2}{|c|}{ Mean for cultivar } & 0.21 & $+5 \%$ & 0.14 & $+17 \%$ & 0.17 & $+6 \%$ \\
\hline \multirow{5}{*}{ 'Filosof' } & $100 \%$ peat & $0.17 \pm 0.005$ & & $0.07 \pm 0.002$ & & $0.12 \pm 0.003$ & \\
\hline & $\begin{array}{l}80 \% \text { peat }+ \\
20 \% \text { perlite } \\
\end{array}$ & $0.20 \pm 0.007$ & $+18 \%$ & $0.11 \pm 0.004$ & $+57 \%$ & $0.16 \pm 0.004$ & $+33 \%$ \\
\hline & $\begin{array}{l}60 \% \text { peat }+ \\
40 \% \text { perlite } \\
\end{array}$ & $0.22 \pm 0.004$ & $+29 \%$ & $0.13 \pm 0.001$ & $+86 \%$ & $0.17 \pm 0.002$ & $+42 \%$ \\
\hline & $\begin{array}{l}40 \% \text { peat }+ \\
60 \% \text { perlite } \\
\end{array}$ & $0.22 \pm 0.011$ & $+29 \%$ & $0.13 \pm 0.011$ & $+86 \%$ & $0.17 \pm 0.011$ & $+42 \%$ \\
\hline & $\begin{array}{l}20 \% \text { peat }+ \\
80 \% \text { perlite } \\
\end{array}$ & $0.09 \pm 0.012$ & $-47 \%$ & $0.09 \pm 0.009$ & $+29 \%$ & $0.09 \pm 0.004$ & $-25 \%$ \\
\hline \multicolumn{2}{|c|}{ Mean for cultivar } & 0.18 & & 0.11 & & 0.14 & \\
\hline \multirow{5}{*}{$\begin{array}{l}\text { Mean for sub- } \\
\text { strate }\end{array}$} & $100 \%$ peat & 0.19 & & 0.10 & & 0.14 & \\
\hline & $\begin{array}{l}80 \% \text { peat }+ \\
20 \% \text { perlite } \\
\end{array}$ & 0.22 & & 0.13 & & 0.18 & \\
\hline & $\begin{array}{l}60 \% \text { peat }+ \\
40 \% \text { perlite } \\
\end{array}$ & 0.23 & & 0.15 & & 0.18 & \\
\hline & $\begin{array}{l}40 \% \text { peat }+ \\
60 \% \text { perlite } \\
\end{array}$ & 0.23 & & 0.14 & & 0.18 & \\
\hline & $\begin{array}{l}20 \% \text { peat }+ \\
80 \% \text { perlite }\end{array}$ & 0.13 & & 0.10 & & 0.11 & \\
\hline
\end{tabular}

LSD $_{0.05}$ essential oils: year -0.3 ; cultivar -0.2 ; substrate -0.2 . 
A determining influence on the accumulation of essential oil in basil of both cultivars had substrate factor (the share of substrate factor influence was $66.5 \%$ ).

\section{CONCLUSIONS}

A rate of perlite in the mixture with peat influences the fresh and dry mass and the concentration of total phenolic compounds, ascorbic acid, carotenoids, as well as essential oil of basil plants. The best combination of peat and perlite was $60: 40 \%$ and $40: 60 \%$, but it was modified by genotype and year of study.

\section{REFERENCES}

Atoui A.K., Mansouri A., Boskou G., Kefalas P. 2005. Tea and herbal infusions: Their antioxidant activity and phenolic profile. Food Chemistry 89(1): 27-36. DOI: 10.1016/j.foodchem.2004.01.075.

Bozin B., Mimica-Dukic N., Samojlik I., Jovin E. 2007. Antimicrobial and antioxidant properties of rosemary and sage (Rosmarinus officinalis L. and Salvia officinalis L., Lamiaceae) essential oils. Journal of Agricultural and Food Chemistry 55(19): 7879 7885. DOI: $10.1021 / \mathrm{jf0715323.}$

Bunrathep S., Palanuvej C., Ruangrungsi N. 2007. Chemical compositions and antioxidative activities of essential oils from four Ocimum species endemic to Thailand. Journal of Health Research 21(3): 201-206.

Chang X., Alderson P.G., Wright C.J. 2008. Solar irradiance level alters the growth of basil (Ocimum basilicum L.) and its content of volatile oils. Environmental and Experimental Botany 63: 216-223. DOI: 10.1016/j.envexpbot.2007.10.017.

Dapkevicius A., Venskutonis R., van Beek T.A., Linssen J.P.H. 1998. Antioxidant activity of extracts obtained by different isolation procedures from some aromatic herbs grown in Lithuania. Journal of the Science of Food and Agriculture 77(1): 140-146. DOI: 10.1002/(SICI)1097-0010(199805)77:1<140::AIDJSFA18>3.0.CO;2-K.

DSTU 4373:2005. 2006. Fruits, vegetables and derived products. Determination of polyphenols content. Kyiv, National Standard of Ukraine, Derzhspozhivstandart 10.

Dumbravă D.G., Moldovan C., Raba D.N., Popa M.V. 2012. Vitamin C, chlorophylls, carotenoids and xanthophylls content in some basil (Ocimum basilicum L.) and rosemary (Rosmarinus officinalis L.) leaves extracts. Journal of Agroalimentary Processes and Technologies 18(3): 253-258.

Hawrylak-Nowak B. 2008. Enhanced selenium content in sweet basil (Ocimum basilicum L.) by foliar fertilization. Vegetable Crops Research Bulletin 69: 63-72. DOI: 10.2478/v10032-008-0021-4.

Heidari M., Golpayegani A. 2012. Effects of water stress and inoculation with plant growth promoting rhizobacteria (PGPR) on antioxidant status and photosynthetic pigments in basil (Ocimum basilicum L.). Journal of the Saudi Society of Agricultural Sciences 11(1): 57-61. DOI: 10.1016/j.jssas.2011.09.001.

Holland B., Unwin I.D., Buss D.H. 1991. Vegetables, herbs and spices: Fifth supplement to McCance and Widdowson's The Composition of Foods. Royal Society of Chemistry, Cambridge.

Juliani H.R., Simon J.E. 2002. Antioxidant activity of basil. In: Janick J., Whipkey A. (Eds.), Trends in new crops and new uses. ASHS Press, Alexandria, VA, pp. 575-579.

Katalinic V., Milos M., Kulisic T., Jukic M. 2006. Screening of 70 medicinal plant extracts for antioxidant capacity and total phenols. Food Chemistry 94(4): 550-557. DOI: $10.1016 /$ j.foodchem.2004.12.004.

Kopsell D.A., Kopsell D.E., Curran-Celentano J. 2005. Carotenoid and chlorophyll pigments in sweet basil grown in the field and greenhouse. HortScience 40(5): 1230-1233.

Kwee E.M., Niemeyer E.D. 2011. Variations in phenolic composition and antioxidant properties among 15 basil (Ocimum basilicum L.) cultivars. Food Chemistry 128(4): 1044-1050. DOI: $10.1016 /$ j.foodchem.2011.04.011.

Makri O., Kintzios S. 2008. Ocimum sp.(basil): botany, cultivation, pharmaceutical properties, and biotechnology. Journal of Herbs, Spices and Medicinal Plants 13(3): 123-150. DOI: 10.1300/J044v13n03_10.

Matea C.T., Soran M.L., Pintea A. Bele C. 2010. Analytical determination of carotenoids in inland Ocimum basilicum L. Bulletin of University of Agricultural Sciences and Veterinary Medicine Cluj-Napoca, Agriculture 67(2): 298-302.

Mortensen A., Skibsted L.H., Truscott T.G. 2001. The interaction of dietary carotenoids with radical species. Archives of Biochemistry and Biophysics 385(1): 13-19. DOI: 10.1006/abbi.2000.2172. 
Musiyenko M.M., Parshykova T.V., Slavnyi P.S. 2001. Spectrophotometric methods in physiology, biochemistry and ecology of plants. Fitosociocenter, Kyiv, 200 p.

Naichenko V.M. 2001. Practicum on technology of storage and processing of fruits and vegetables. Kyiv, FADA Ltd., $211 \mathrm{p}$.

Nguyen P.M., Niemeyer E.D. 2008. Effects of nitrogen fertilization on the phenolic composition and antioxidant properties of basil (Ocimum basilicum L.). Journal of Agricultural and Food Chemistry 56(18): 8685-8691. DOI: 10.1021/jf801485u.

Nurzyńska-Wierdak R. 2012. Ocimum basilicum L. a valuable spice, medicinal and oleiferous plant. Annales Universitatis Mariae Curie-Skłodowska, Horticultura 22(1): 20-30. [in Polish with English abstract]

Proestos C., Chorianopoulos N., Nychas G.-J.E., Komaitis M. 2005. RP-HPLC analysis of the phenolic compounds of plant extracts. Investigation of their antioxidant capacity and antimicrobial activity. Journal of Agricultural and Food Chemistry 53(4): 1190-1195. DOI: 10.1021/jf040083t.

Shan B., Cai Y.Z., Sun M., Corke H. 2005. Antioxidant capacity of 26 spice extracts and characterization of their phenolic constituents. Journal of Agricultural and Food Chemistry 53(20): 7749-7759. DOI: 10.1021/jf051513y.

Shiga T., Shoji K., Shimada H., Hashida S., Goto F., Yoshihara T. 2009. Effect of light quality on rosmarinic acid content and antioxidant activity of sweet basil, Ocimum basilicum L. Plant Biotechnology 26(2): 255-259. DOI: 10.5511/plantbiotechnology.26.255.

Shoji K., Goto E., Hashida S., Goto F., Yoshihara T. 2009. Effect of light quality on the polyphenol con- tent and antioxidant activity of sweet basil (Ocimum basilicum L.). Acta Horticulturae 907: 95-99. DOI: 10.17660/ActaHortic.2011.907.10.

Škerget M., Kotnik P., Hadolin M., Hraš A.R., Simonič M., Knez Z. 2005. Phenols, proanthocyanidins, flavones and flavonols in some plant materials and their antioxidant activities. Food Chemistry 89(2): 191-198. DOI: $10.1016 /$ j.foodchem.2004.02.025.

Suhaj M. 2006. Spice antioxidants isolation and their antiradical activity: a review. Journal of Food Composition and Analysis 19(6-7): 531-537. DOI: 10.1016/j.jfca.2004.11.005.

Surveswaran S., Cai Y.Z., Corke H., Sun M. 2007. Systematic evaluation of natural phenolic antioxidants from 133 Indian medicinal plants. Food Chemistry 102(3): 938-953. DOI: $10.1016 /$ j.foodchem.2006.06.033.

Tarchoune I., Sgherri C., Baâtour O., Izzo R., Lachaâl M., Navari-Izzo F., Ouerghi Z. 2012. Phenolic acids and total antioxidant activity in Ocimum basilicum L. grown under $\mathrm{Na}_{2} \mathrm{SO}_{4}$ medium. Journal of Medicinal Plants Research 6(48): 5868-5875. DOI: 10.5897/JMPR12.011.

Vardar-Ünlü G., Candan F., Sökmen A., Daferera D., Polissiou M., Sökmen M., Dönmez E., Tepe, B. 2003. Antimicrobial and antioxidant activity of the essential oil and methanol extracts of Thymus pectinatus Fisch. et Mey. var. pectinatus (Lamiaceae). Journal of Agricultural and Food Chemistry 51(1): 63-67. DOI: 10.1021/jf025753e.

Zheng W., Wang S.Y. 2001. Antioxidant activity and phenolic compounds in selected herbs. Journal of Agricultural and Food Chemistry 49(11): 51655170. DOI: $10.1021 /$ jf010697n. 